\title{
Bosnia and Herzegovina as a Historical Balkan Bridge Between Cultures, Religions and Nations
}

\author{
Aleksandr V. Savchenko ${ }^{1}$, Mikhail S. Khmelevskii ${ }^{2}$ \\ ${ }^{1}$ National Chengchi University \\ no. 64, Sec. 2, Zhinan Rd., 116, Wenshan District, Taipei, Taiwan \\ ${ }^{1}$ savchenko75@mail.ru \\ ${ }^{2}$ Saint-Petersburg State University \\ Universitetskaya Emb., 11, Saint-Petersburg, Russian Federation, 195249 \\ ${ }^{2}$ chmelevskij@mail.ru
}

\begin{abstract}
Given article presents an overview and analysis of the facts of the crossing of the Slavic, Oriental and European cultures in the very center of the Balkan Peninsula, as well as the connection of the Orthodox, Catholic and Muslim (Islamic) worlds and mentality in the historical retrospective of Bosnia and Herzegovina, its culture, ethnography and language. Special attention is paid to the specific moments of modern political life, socio-demographic problems, as well as to the peculiarities of the national mentality, traditions and customs of different peoples (formed as a result of confessional differences), living on the territory of modern Bosnia and Herzegovina. On this basis we try to present the specifics and uniqueness of this region: on the one hand, the Slavonic one, and on the other, not being such in the traditional and direct meaning of this word. Along with these questions, stereotyped views of the peoples of the former Yugoslavia on the Muslim part of the population of Bosnia and Herzegovina, their actual implementation in contemporary culture, literature and language, as well as their transformation as a result of the crucial political events of the 1990s, are also considered. In the article it is concluded for the first time that apart from the notions Slavia Orthodoxa and Slavia Romana, traditionally accepted in the science about the Slavs, from the XVI century, the third world - Slavia Muslim with its mentality, culture, religion and language has started to form in the Balkans.
\end{abstract}

Key words: Bosnia, the Balkan, the Balkan Peninsula, South Slavs, South Slavic languages, Multicultural and Multireligious Region, Ethnic Interaction, Yugoslavia

\section{Article history:}

Received: 20.04.2020

Accepted: 10.05.2020

\section{For citation:}

Savchenko, A.V. \& Khmelevskii, M.S. (2020). Bosnia and Herzegovina as a Historical Balkan Bridge Between Cultures, Religions and Nations. RUDN Journal of Language Studies, Semiotics and Semantics, 11 (3), 545-559. doi: 10.22363/2313-2299-2020-11-3-545-559

(C) Савченко А.В., Хмелевский М.С., 2020.

(c) () This work is licensed under a Creative Commons Attribution 4.0 International License https://creativecommons.org/licenses/by/4.0/ 


\title{
Босния и Герцеговина - исторический мост между балканскими культурами, религиями и нациями
}

\author{
А.В. Савченко ${ }^{1}$, М.С. Хмелевский \\ ${ }^{1}$ Государственный университет Чжэнчжи \\ 64/2, улииа Дюсинань, 116, Вэньшань, г. Тайбэй, Тайвань, 195249 \\ ${ }^{1}$ savchenko75@mail.ru \\ ${ }^{2}$ Санкт-Петербургский государственный университет \\ Университетская наб., 11, г. Санкт-Петербург, Российская Федерация, 195249 \\ ${ }^{2}$ chmelevskij@mail.ru
}

В статье представлены основные факты пересечения славянской, восточной и европейской культур в самом центре Балканского полуострова, в исторической ретроспективе рассматриваются их особенности и анализируются связи православного, католического и мусульманского миров, которые нашли отражение в менталитете жителей Боснии и Герцеговины: в культуре, этнографии и языке. Особое внимание уделяется конкретным аспектам современной жизни, а также социальным проблемам, особенностям национального менталитета, традициям и обычаям разных этносов (сформировавшихся в результате конфессиональных различий), проживающих на территории современной Боснии и Герцеговины. На основе проводимого в статье анализа показана специфика и уникальность данного балканского региона: с одной стороны, славянского, а с другой, - не являющегося таковым в культурологическом и мировоззренческом смысле этого слова. В работе также продемонстрированы стереотипные представления народов бывшей Югославии о мусульманской части населения Боснии и Герцеговины, которые нашли свое отражение в современной культуре, литературе и языке всех современных народов Южной Славии. В настоящем исследовании впервые делается вывод о том, что помимо традиционно принятых в науке понятий Slavia Orthodoxa («православная Славия») и Slavia Romana («католическая Славия»), на Балканах с XVI века начал формироваться третий мир - Slavia Muslim («мусульманская Славия») со своим особым своеобразным и локально ограниченным менталитетом, культурой, религией и языком.

Ключевые слова: Босния, Балканы, Балканский полуостров, Южные славяне, южнославянские языки, мультикультурный и мультирелигиозный регион, этническое взаимодействие, Югославия

\section{История статьи:}

Дата поступления: 20.04.2020

Дата приема в печать: 10.05.2020

\section{Для цитирования:}

Savchenko A.V., Khmelevskii M.S. Bosnia and Herzegovina as a Historical Balkan Bridge Between Cultures, Religions and Nations // Вестник Российского университета дружбы народов. Серия: Теория языка. Семиотика. Семантика. 2020. Т. 11. по 3. С. 545-559. doi: 10.22363/23132299-2020-11-3-545-559

\section{Introduction}

The Balkan Slavic Region is, from an historical and cultural point of view, one of the most interesting regions in Europe and in the whole world. In this region we recognize international and specific points, space, which illustrate different processes in history, culture and traditions of different Slavic nations: 
their languages, customs, and religions. The Balkans are also a kind of bridge between Europe and Asia, as they connect Western and Eastern cultures [1].

Bosnia, which is situated in Southeastern Europe, i.e. in the west part of the Balkan Peninsula, is like a connecting link or bridge between the Orthodox East and Catholic West as well as the Muslim Orient on the border of two worlds namely that of the former Ottoman and Austro-Hungarian Empires. Having combined these cultures, this region has developed a unique atmosphere, in which Orthodoxy and Catholicism, Islam and atheism, originally Slavic, Gypsy and Jewish cultures, Balkan mentality and modern European globalization merge. Slavic, Middle Eastern and European art, music, fashion, food etc. intricately intermingled here. Such kinds of connections can be really called the essence of the Bosnian World [2. P. 79].

Being situated on the crossroads of different cultures, Bosnia and Herzegovina have become a region, interesting and varied from the historical point of view: Bosnian kings and Turkish governors, Austro-Hungarian dukes (Herzegovina) and Serbian kings, Yugoslavian Communists and modern presidents ruled here, and the latter now rule the country jointly, i.e. one president from each national minority lives on this territory. All Slavic peoples living in the Balkan say of themselves ironically: "Sagradili smo kuću na drumu" (We've built our house on a road, i.e. on a crossroad). This phrase is usually used as a joke about different Slavic Balkan countries. This is the region, where also the First World War started. It began from the assassination of the archduke Franz Ferdinand by Gavrilo Princip in Sarajevo on the Latin Bridge.

Nowadays Bosnia-Herzegovina has become a multicultural, multireligious and multinational center of the entire Balkan Peninsula and its art, arising in such unique and diverse environment, goes far beyond the country's borders: people listen to the music of Goran Bregović, watch the movies of Emir Kusturica, read the novels of the Nobel Prize laureate writer Ivo Andrić.

Sarajevo is one of the largest political, economic and cultural centers of the Balkans and the capital city of Bosnia-Herzegovina. The history of Sarajevo traces its roots back into the centuries: already since XIII century this city has been the center of various influences, which had been coming to the Balkans from all over the world, and in the course of time they were being changed and adjusted to the value system of the local Slavic population with its Balkan mentality; and step by step these influences and multicultural customs took roots here interweaving with indigenous customs and traditions that as a result have given the city its unique character. Thanks to the interconnection in the organic whole in one place of Oriental Islamic, Western Catholic, Orthodox Byzantine, Jewish and Gipsy cultures, Sarajevo has earned a second metaphorical name - The European Jerusalem.

It is seen in Sarajevo's architecture: each stone in this city keeps its history - old Muslim center with Islamic architecture, a labyrinth of little streets and an amazing smell of Bosnian coffee surrounded by strict and majestic 
buildings in the Austro-Hungarian style, but just a couple of steps away and you are already in pompous Stalin's-Tito's style districts of the former Yugoslavia.

Sarajevo is not only a bridge between the West and the East, but it has got the glory of the bohemian city: it is like Mecca for people of art, i.e. for various artists: writers and poets, painters and philosophers, composers and musician, filmmakers, producers and actors, who are nowadays well-known all over the world.

Here could be easily found the tracks of Slavonic, eastern and European cultures, Orthodox, Catholic and Muslim (Islamic) elements in the national mentality both in history and culture, history, ethnography and language. The given region is Slavic by its nature, but at the same time not quite Slavic in the conventional sense of the word.

\section{Research Methodology}

Our observations are based on empirical material collected in the course of field research in the sphere of linguoculturology conducted in the different regions of Bosnia and Herzegovina in the period from 2008 to 2019. In this article, we use an approach based on the theoretical works of such scientists as e.g. W. Browne, J.A. Fishman, R D. Greenberg, R. Bugarski, R. Katičić, H.D. Pohl, M. Mazower, A. Pramenković [3-12], and other researchers, both linguists and historians.

Important role during the conducting of given research plays popular concept in political sciences and sociology represented by B. Anderson [13] and in sociolinguistic by W. Labov [14].

Given study takes into account the main important factors that influence the history and culture of the Balkans: among them are (a) Ottoman cultural influences, (b) establishment of local national regimes at the beginning of the twentieth century and the rule of Austro-Hungarian Monarchy in certain parts of the region, (c) establishment of Communist regime in the aftermath of WWII (except for Greece), and (d) liberalization of state-religion relations encouraged by democratic processes [15. P. 3], historical aspects are analyzed taking into account such works as, in particular, F. Karčić [16], F. Friedman [17], some religious aspects we interpret on the base of S. H. Nasr [18], common linguoculturological facts also contain A. Smajić [19], J.W.Tollefson [20], I. Lovrenović [21], I.V. Kuznetsova [22].

\section{Sociological and Multinational Aspect}

The ethnic situation in this region is quite unique, because historically on these territories, i.e. the territory of Bosnia and Herzegovina, several nations live together, having formed from the same ethnic group, the Southern Slavs. As a result of acceptance by them different religions, this common ethnic group was divided into several ethnic groups. It should be noted that religion on the Balkan Peninsula in general is the most important and the most influential factor in the formation and development of nations. Here live Bosniaks, i.e. former Catholics 
and Orthodox (Serbs and Croats), who converted to Islam in the XVI century when Bosnia became a part of the Ottoman Empire, and then they inherited Muslim (Islamic) culture together with local Bosnian features, as well as Croats, who are also Slavs, but the religion they practice is Catholicism, and Orthodox Serbs. As the professor of the Berlgrade University R. Bugarski has remarked, alone among the Yugoslav republics, Bosnia-Herzegovina had no absolute national majority, being split three ways into Moslems (this last a national rather than confessional identification), Serbs and Croats [6. P. 74]. They do not differ from each other neither in appearance nor in language (although they call one common language differently, depending on their formal nationality: Serbian, Croatian, and Bosnian (even so called Bosniac that's the language of Bosniaks), but it's very important to underline the question of national identity: Bosnian Muslims, or Bosniaks, don't feel themselves as a Slavic nation, and ordinary Serbian people also don't feel them as a Slavic nation, although historical, ethnological and linguistics facts say the opposite. The acts of converting religions (i.e. nations) is relatively common phenomenon in the history of Slavic Balkan, that is why there is a commonly used phrase in the language: "Ne zna čovjek u kojoj će vjeri umrijeti" (Nobody knows in which religion he will die), which is often used about something in the meaning like "no fence against a flail" or "one is never safe from misfortune and trouble", i.e. this phrase isn't about religion, but destiny [23. P. 231].

Nevertheless, at the same time the difference between them lies in the mentality, which was formed by the religion chosen long time ago, as well as in their habits and in their looks. Thus, Bosnia and Herzegovina is a state association of three ethnic groups, or, officially "constitutive peoples": of Bosnia and Herzegovina (this term was created especially for the unique ethnic and social situation in modern Bosnia and Herzegovina), that is reflected on the coat of arms of the state: on the blue-colored background in the form of a map of the country with a number of white stars, symbolizing belongingness to Europe, a yellow triangle, symbolizing in its turn a peaceful coexistence of the two nations, is located. Besides, less than $10 \%$ of the total population identify themselves as "Yugoslavians" - some kind of a peculiar quasi-ethnonym, which allows freely to determine their national belonging, national identity, or, vice versa, nonidentity, non-belonging — mostly it is children of mixed marriages or atheists.

Besides Slavs of different beliefs and confessions here from the immemorial time live Gypsies, whose culture has deeply penetrated into the consciousness of all the three Slavic Nations, and also a significant mark on this territory left Jews, who were expelled in the 15th century from Spain and found refuge in the Ottoman Empire (in Sarajevo there are 2 synagogues and the Jewish cemetery).

\section{Political Aspect}

Modern Bosnia-Herzegovina is a special state formation, which appeared on the political world map as a result of the signing of the Dayton Peace Agreement 
(1995). It consists of the Muslim-Catholic Federation of Bosnia and Herzegovina and the Republika Srpska (with the capital in Banja Luka after the last Balkan war of 90-th and according to the Dayton Agreement) with the overwhelming majority of the Orthodox population altogether comprising two entities (Federation of Bosnia and Herzegovina $(\mathrm{BiH})$ and Republika Srpska (RS)). In the north of the country also lies its other part — the so-called The Brčko District, having a special status as a buffer zone between the two parts of Republika Srpska. It unites both parts of Republika Srpska and it is a neutral, self-governed administrative unit: it does not formally belong to either the Federation of $\mathrm{BiH}$ or to the Republika Srpska. All these entities are self-governed without the right to secession, i.e. withdrawal from the unified state. In its political structure Bosnia-Herzegovina is unique in the world.

At the head of the state there are three presidents representing the three constituent peoples. Each of these three presidents every eight months successively takes the highest post in the country. On one hand, the Federation of $\mathrm{BiH}$ elects its president from the Muslims and Croats; the Republika Srpska in turn elects the president from the Orthodox part of the population (incidentally, the same rule applies to the elections of the Football Association of Bosnia and Herzegovina). Although by its nature the state of Bosnia and Herzegovina has the status of a republic, in practice it is not a real republic due to the complexity of its internal political structure. Thus the state has features both of federation and confederation. The borders between entities and cantons divide the whole territory not so much formally as mentally: a citizen of RS hardly recognizes the coexistence of one united state with the Muslim-Catholic Federation. In their turn, Muslim-Catholic residents normally do not cross the formally missing border of the Republika Srpska.

The political and social situation is complicated by the fact that inside of the Federation itself there could be found "mental" boundaries between Catholics and Muslims. A vivid and very illustrative example of this is the city of Mostar on the Neretva River: the bridge, which connects two banks, divides the city into Catholic and Muslim parts. Local people usually do not cross this bridge but stay in their own world and pray to their own gods. Moreover, in everyday life they buy goods made by "their own" manufacturers only: Croatian ones or from Sarajevo (in particular, chocolate, beer, mineral water, etc.).

A similar situation can be observed in many other cities of the country, including Sarajevo, in which, according to the Dayton Agreement, the border between $\mathrm{BiH}$ and $\mathrm{RS}$ runs through the city. The part of the city Sarajevo belonging to RS represents quite a different world, which differs from the rest of the city: with Orthodox churches, its inhabitants consider themselves as Serbs or Yugoslavians. They don't cross a notional boundary between BiH and RS. In this part of the city we could hardly find traces of Muslim or Catholic culture, to the extent that in this part of the city it's possible to buy only goods, produced in RS only or in nearby Serbia. Before the war in the 90's this suburban area of the city of Sarajevo was 
called Pale, and until now in the spoken language this title was used for the name of a Serbian part of the city Sarajevo, whereas officially immediately after the war this part was called Srpsko Sarajevo (Serbian Sarajevo) and nowadays - Novo Sarajevo (New Sarajevo), or Istočno Sarajevo (The East Sarajevo).

The modern uneasy political situation in $\mathrm{BiH}$ is a result of the war of the 90's, which has become one of the largest, cruelest, and bloodiest war conflicts in Europe after the Second World War. As one of the causes of the war many "Yugoslavians" usually say, that it's connected with the controversial figure of the former Head of ex-Yugoslavia - Josip Broz Tito. In the 70's he announced that his biggest political merit was to make a country in which all these different nations lived peacefully together [24]. He had achieved great success in politics and had attained great popularity, which is why nowadays the cult of Tito is very popular among Serbians, Croats and especially Bosnians, even among young people who didn't live in Tito's Yugoslavia. The evidences of this cult we may find in the language: e.g. a common phrase Tita mi, which is used with meaning ,Believe me', ,I'm telling the truth', ,I swear' (with different variants, like: Boga mi, života mi, majke mi, i.e. ,I swear to God, to my life, to my mother') quite clearly illustrates this cult [25. P. 48].

On the other hand, Tito succeeding in making "happy" his multinational country untill his death in 1980, but in the early 90-th all the national problems, which were hidden by Tito's ideology and dreams about multinational "happiness", began to grow and immediatly exploded and resulted in fratricidal war. This historical fact can be illustrated by a phrase of a modern popular Balkan poet and singer Bajaga: "Tu svako može biti dušman i brat", i.e. here everybody can be (at the same time) a brother and an enemy.

\section{Postwar '90s Period}

The mentality and consciousness of the citizens of Bosnia and Herzegovina were greatly influenced by the Civil War in the early 90s. This war (1992-95) has had a tremendous impact on the further history and social development of Bosnian society. As well-known Balkan writer Ivo Andrić wrote, the interethnic hatred that burst out during this cruel and bloody conflict had "a certain function in the social development". On the one hand, it has given birth to the modern consciousness of alienation from each other; on the other hand, it has deeply rooted in contemporary consciousness, separating for decades people, which used to be at one time neighboring, and drawing boundaries in their minds [11. P. 38]. We are not expected to support any of those opposing sides, however, it should be emphasized, that "the rage" I. Andrić wrote about has formed the modern consciousness of the inhabitants of today's Bosnia and Herzegovina, as well as other neighboring people: Serbs, Croats, and Montenegrins. This "Rage" has created boundaries in the minds of ordinary inhabitants, a kind of a "Berlin wall", that doesn't exist in reality and isn't marked on maps, but psychologically doesn't 
allow a resident of East Sarajevo to take a trolleybus and get to the Muslims' part of the city. Moreover, Eastern Orthodox part of the city of Sarajevo is completely absent on the map, as if not existing, and for a Catholic Croat to cross the bridge over the River Neretva and find himself in the Muslim part of the city Mostar is even hard to imagine.

Nowadays the country lives and continues developing, but is constantly reminded about the recent fratricidal war by the firearms traces on the dwelling houses and administrative buildings in every town in Bosnia, by the signs with the inscription "Danger - Mines!", and endless cemeteries on the sites of the former parks, or half-ruined buildings with traces of the bombs. In the small city Srebrenica a memorial complex was built to remind the victims of genocide during this war. Sarajevo's suburb there is a museum on the spot, where under the Sarajevo International Airport a tunnel for food and weapon delivery was dug during the almost four-year siege of Sarajevo by the Yugoslav People's Army (YPA) and the Army of Republika Srpska [6. P. 75].

\section{Cultural Aspect}

An interesting fact is, that today all Balkan people: Serbs, Croats, Bosnian Muslims, Montenegrins often ironically say: "Jebem zemlju koja Bosne nema" (which more or less could be translated literally in this manner: "I don't care about a country, which doesn't have Bosnia"), which after the war conflict of the 90-th has been transformed in common language to Jadna je zemlja koja Bosnu ima (Pure is a country, which has Bosnia). On one hand, it is a good example of a very special and outstanding Balkan sense of humor, but on the other hand, under this "idiomatic expression" a great metaphorical meaning is hidden, because this country on the whole and, first of all, Sarajevo represents by itself a center of Balkan culture. It is the place where various artists live and create their works of art: writers, painters, musicians...

For sure, we should mention so-called Bosnian bards and especially their special Bosnian musical folk style Sevdalinka also known as Sevdah music. Almost every citizen of Sarajevo, dropping into a café for a glass of Rakija (a Balkan type of fruit brandy) or a cup of coffee in the $K a(h) f a n a$ (a little restaurant), like Ernest Hemingway, is used to writing poems on a serviette or think over something in his head, or discuss politics with a waiter, or just enjoy music of the trams, which are whizzing past, and at the same time, he internally considers himself as a pjesnik, i.e. a poet and a musician in the broad sense of the word. That is the Bosnia, where the Nobel Prize winner "Yugoslav" Ivo Andrić came from, it's the streets of the city Sarajevo, where, thinking over the plot of his novels, another great writer, also "Yugoslav" Mehmed "Meša" Selimović walked down. It is Sarajevo, where from all former Yugoslavia gathered dissidents, rockmusicians, unrecognized artists, and as a result of this process exactly here arose well-known in the Balkans and far beyond of their borders singers, writers, artists, 
actors and filmmakers. It is Sarajevo, where a unique international film festival is held annually.

During the times of the former socialist "Tito's" Yugoslavia to visit Sarajevo was like to visit Mecca: everyone from Ljubljana to Skopje (as it was sung in one very popular song that has become an almost unofficial anthem of Tito's Yugoslavia Od Vardara do Triglva) felt obligated to come here to give honor to the city, which lies in his heart and is part of his inner world.

Unfortunately, the war has altered a lot on the map of Bosnia and Sarajevo, but the country has survived and continued living and developing; a normal life in the country has recovered and goes on, overcoming various difficulties, in particular, difficulties of multiethnic cohabitation. And the only thing that, with no doubts, continues connecting these three unfriendly to each other nations is their common culture, music and art: Muslims listen to Croatian musicians, Serbs are fond of singers from Bosnia and Sarajevo, Croats enthusiastically, heartily and eagerly welcome entertainers from Serbia, and the Nobel Prize Winner Ivo Andrić is commonly considered as "a Great Yugoslavian Writer".

\section{Multicultural Aspect}

In Bosnia Muslim, Orthodox, Catholic, and Jewish cultures historically interconnected and coexisted, the real evidence of which is a number of architectural monuments, primarily of religious nature. Christian cemeteries are often situated next to Muslim and Jewish ones. As a significant and remarkable example one passage from Ivo Andrić Story Letter from 1920 could be cited:

Whoever lies awake at night in Sarajevo hears the voices of the Sarajevo night. The clock on the Catholic cathedral strikes the hour with weighty confidence: 2 AM. More than a minute passes (to be exact, seventy-five seconds - I counted) and only then with a rather weaker, but piercing sound does the Orthodox church announce the hour, and chime its own 2 AM. A moment after it the tower clock on the Beys' mosque strikes the hour in a hoarse, faraway voice, and that strikes 11, the ghostly Turkish hour, by the strange calculation of distant and alien parts of the world. The Jews have no clock to sound their hour, so God alone knows what time it is for them by the Sephardic reckoning or the Ashkenazy. Thus at night, while everyone is sleeping, division keeps vigil in the counting of the late, small hours, and separates these sleeping people who, awake, rejoice and mourn, feast and fast by four different and antagonistic calendars, and send all their prayers and wishes to one heaven in four different ecclesiastical languages. And this difference, sometimes visible and open, sometimes invisible and hidden, is always similar to hatred, and often completely identical with it. And one more important emphatic addition in the very next sentence that could become the motto of our article: "This uniquely Bosnian hatred should be studied and eradicated like some pernicious, deeply-rooted disease” [26]. 
In different historical periods people, living on the territory of Bosnia, experienced the influence of Venice, Austria-Hungary, Ottoman Empire, and through the latter they were influenced by the Arabian and Persian cultures (until XX century Turkish and Arab languages had in Bosnia an official status in the business sphere; Persian, in its turn, was an advanced language of poetry). Later, it had also experienced the influence of the ideas of pan-Balkan unity within the Kingdom of Serbs, Croats and Slovenes, as well as the Communist ideology in the times of Tito's Yugoslavia, reactionary nationalist ideas during the Civil war of 1992 - 95 years and in the latest, modern period of Bosnia's history - the ideas of globalization and European unity and integration.

In summary we can once again mention Ivo Andric and his words: "Yes, Bosnia is a country of hatred. That is Bosnia". We dare not forget his important (unfortunately, very apt for all epochs of social development) statement from the above cited work: "I know that hatred, like anger, has its function in the development of society, because hatred gives strength, and anger provokes action". In general, "The idea of peace and dialogue in the Balkans is of utmost importance because of the fact that almost the entire history of the Balkans may be seen as periods between wars or between peace treaties" [12. P. 116].

\section{Language Question}

The very complicated situation has developed as well in the language policy of modern Bosnia, where at the end of the '90s the following official languages were recognized Bosnian, Croatian and Serbian (with the exception of Republika Srpska, where in the Constitution only Serbian is declared an official national (resp. state) language) [27].

In this connection we should mention as well, that the language situation in former Yugoslavia also was multicultural, polylingual as well as complicated. Out of the twenty seven idioms only fourteen are used in official and public communication in their standard forms: Albanian, Bulgarian, Czech, Hungarian, Italian, Macedonian, Romany, Romanian, Rusyn, Serbo-Croatian, Slovak, Slovene, Turkish and Ukrainian: speakers of these languages constitute $98.6 \%$ of the Yugoslav population [28]. At the same time, the Serbian and Croatian languages so similar (though they use different scripts) that one could speak of Serbo-Croatian language, thus reducing the number of language to three. In fact government policy through the educational system was to promote the idea of a single Serbo-Croatian language" [29. P. 19].

This "Language question" is very essential both for linguists and native speakers. As it mentioned M. Kovačić, Serbian and Croatian languages are closely related but not identical. Similarities between them are superficial, while differences are found more deeply, and many of them are based on subtleties, preferences, semantic nuances, caused by discrepancies between what is attempting to be standard and what is colloquial and by the political instability 
(which resulted in the emergence of languages such as Bosnian). They certainly deserve more attention and studying, instead of being ignored by considering the two languages as politically designated variants of one, thus maintaining the confusion among native speakers and foreigners alike or taken into account out of nothing more than tolerance [30. P. 203-204].

In general, the term "The Bosnian language" sporadically occurs in legal documents and fiction beginning with the XV century (in 1890 was published the first Grammar by Franko Vuletić «Gramatika bosanskoga jezika za srednje škole» (Bosnian grammar for the Secondary school), which was republished in 1908 under the title «Gramatika srpsko-hrvatskog jezika» (Grammar of the SerbianCroatian Language)). More detailly the historical aspect of the development of the so called Bosnian language is described, in particular, in the scientific works of L. Staničić [31], D.Vujičić [32], A. Šehović and Đ. Haverić [33] and others.

The "Bosnian language" has been experiencing its greatest actualization since the '90s since the gaining of Bosnia's statehood. Since that time this has become an official linguistic term and at the same time the standardization of Bosnian has been sought. Despite the fact that there are a large number of disagreements over such a term in the modern Slavistic, e.g. Serbian and Russian Slavists don't recognize it as an independent language, having relegated it to the Serbian, resp. Serbo-Croatian, in world practice and among linguists it has been given the status of an officially recognized language (for instance in such organisations as International Organization for Standardization, United Nations, UNESCO). Moreover, this term is normally used on the state level (e.g. the Constitution of Montenegro defines the State languages as follows: Montenegrian, Serbian, Croatian, Bosnian and Albanian).

Pure linguistic differences between Bosnian from Serbian or Croatian are minimal and not so conspicuous, which is why nowadays in world practice official names of the language are often used such as Serbo-Croat-Bosnian (SCB), BosnianCroatian-Serbian (BCS), or Bosnian-Croatian-Montenegrin-Serbian (BCMS) [27].

As for the citizens of the Muslim part of Bosnia and their spoken "bosanski jezik" (Bosnian language), such expressions as "naš jezik, maternji jezik" (our language, mother language) can be heard [34]. The Macedonian language underwent a similar process in its historical development - as did the languages within Montenegro and even Serbia as well [7. P. 201]. As a rule, such "selfdefinitions" try to escape misunderstandings and mask inconveniences in the process of communication between speakers in different regions.

Apart from some phonetic differences that are typical for the whole territory of the BCMS, the Bosnian language has also absorbed and acquired a great number of words that are Turkish in origin (so-called "Turkisms"), which would normally have Slavic equivalents and could be replaced interchangeably with them [8. P. 84]. Such Turkisms are easily recognized both in Zagreb, and in Belgrade, but such words are very remarkable and correlated with the cultural and linguistic specifics of Bosnia. Besides Turkisms, an essential part of Bosnian 
vocabulary comprise Persian ad Arab words, which are normally used in the religious sphere [35. P. 68].

In any case, despite their being much debate in the modern Slavistics, the term "Bosnian language" has become customary in official political use, particularly in the sphere of international relations and translation (e.g., amongst accredited interpretation agencies and internet translation services). From the linguistic point of view, in relation to this linguistic phenomenon, it would be more appropriate / most accurate to use the term "ethnolect" i.e. a variety of a language associated with a certain ethnic or cultural (resp. religious) subgroup [35]. A highly important and most interesting problem remains the variant of an "ethnolect" and the religious affiliations of language speakers, but this would be a topic for another detailed research.

\section{Conclusion}

The Balkan Peninsula is one of the most complicated from the sides of history and culture, among this region, former Yugoslavia as a country perfectly represented how complex it is. There is a saying to describe this state, "Yugoslavia was popularly described as consisting of: seven frontiers, six republics, five nationalities, four languages, three religions, two alphabets and one boss" [36. P. 5]. This "boss", the leader of Yugoslavia, Josip Broz Tito, expressed this idea almost the same words: "I am the leader of one country which has two alphabets, three languages, four religions, five nationalities, six republics, surrounded by seven neighbours, a country in which live eight ethnic minorities" [37. P. 238].

Thus, in the modern Bosnia and Herzegovina we can recognize three cultures at once, comprehend the history of different epochs and influences - Balkan, Austro-Hungarian, Orthodox, see with our own eyes the traces of Socialist, Tito's Yugoslavia and the post-Yugoslavian war, and also observe its peaceful present.

\section{References}

1. Jelavich, B. (1983). History of the Balkans, Vol. 1: Eighteenth and Nineteenth Centuries. Cambridge University Press.

2. Khmelevskii, M.S. (2015). Otrazhenie istorii, kultury i tradiciy Bosnii v yazyke i frazeologii. Studia Slavica Academiae Scientiarum Hungaricae, 60 (1), 79-86. DOI: https://doi.org/ 10.1556/060.2015.60.1.8. (In Russ.).

3. Browne, W. (1993). Serbo-Croat. In: The Slavonic languages, Bernard Comrie and Greville G. Corbett (eds.). London-New York: Routledge. pp. 306-387.

4. Fishman, J.A. (1962). The Language Factor in National Development. Anthropological Linguistics, 4 (1), 23-27.

5. Greenberg, R.D. (2008). Language and identity in the Balkans: Serbo-Croatian and its disintegration. Oxford: Oxford University Press.

6. Bugarski, R. (2001). Language, nationalism and war in Yugoslavia. International Journal of the Sociology of Language, 151, 69-87. DOI: https://doi.org/10.1515/ijsl.2001.048.

7. Bugarski, R. (2004). Language policies in the successor states of former Yugoslavia. Journal of Language and Politics, 3 (2), 189-207. DOI: https://doi.org/10.1075/jlp.3.2.04bug.

8. Bugarski, R. (2012). Portret jednog jezika / Urednik Ivan Čolović. Biblioteka XX vek, Knj. 201. Beograd: Knjižara krug. (In Serb.). 
9. Katičić, R. (1997). Undoing a "Unified Language": Bosnian, Croatian, Serbian In: Undoing and Redoing Corpus Planning. Clyne M. (ed.). Berlin: Mouton de Gruyter. pp. 165-191.

10. Pohl, H.D. (1996). Serbokroatisch - Rückblick ind Ausblick In: Wechselbeziehungen zwischen Slawischen Sprachen, Literaturen und Kulturen in Vergangenheit und Gegenwart. Ingeborg Ohnheiser (ed). Innsbruck: Istitut für Sprachwissenschaft. pp. 205-221. (In Germ.).

11. Mazower, M. (2002). The Balkans. Short History. New York: Modern Library.

12. Pramenković, A. (2012). Muslims and Christians in the Balkans: Historical Aspect and Contemporary Challenges Dialogue without Alternative. Milel ve Nihal: Inanç, Kültür ve Mitoloji Araştirmalari, 9 (2), 113-122.

13. Anderson, B. (2006). Imagined Communities: Reflections on the Origin and Spread of Nationalism. London, New York: Verso, Revised edition.

14. Labov, W. (1972). Sociolinguistic Patterns. Philadelphia: University of Pennsylvania Press.

15. Isanović-Hadžiomerović, A. (2018). Islamic Education in the Balkans. In: Daun H., Arjmand R. (eds.) Handbook of Islamic Education. International Handbooks of Religion and Education, 7. Springer, Cham. DOI: https://doi.org/10.1007/978-3-319-64683-1_47.

16. Karčić, F. (1999). The Bosniaks and the challenges of modernity: Late Ottoman and Habsburg times. Sarajevo: El-Kalem.

17. Friedman, F. (2006). Bosnia and Herzegovina: A polity on the brink. London and New York: Routledge. Taylor \& Francis Group.

18. Nasr, S.H. (2009). Islam: Religion, history, and culture. New York: HarperCollins.

19. Smajić, A. (2014). Bosnia and Herzegovina. In: J.S. Nielsen et al. (eds.), Yearbook of Muslims in Europe, 6. Leiden: Brill. pp. 108-127.

20. Tollefson, J. W. (2002). The language debates: preparing for the war in Yugoslavia, 19801991. International Journal of the Sociology of Language, 154, 65-82.

21. Lovrenović, I. (2002). Bosanski Hrvati. Esej o agoniji jedne evropsko-orijentalne mikrokulture. Zagreb: Durieux. (In Croat.).

22. Kuznetsova, I.V. (2017). Ustojchivye sravneniya s personazhami Biblii v yazykah byvshej Yugoslavii In: Studia Slavica Academiae Scientiarum Hungaricae, 62 (1). Budapest: Akadémiai Kiadó. pp. 77 — 90. DOI: https://doi.org/10.1556/060.2017.62.1.7. (In Russ.).

23. Khmelevskii, M.S. (2013). Osobennosti frazeologii goroda Sarajeva In: Nacionalnoye $i$ internacionalnoye $v$ slavyanskoy frazeologii. Greifswald: Ernst-Moritz-Arndt-Universität. pp. 227 -231. (In Russ.).

24. Fischer, B.J. (eds.). (2007). Balkan Strongmen: Dictators and Authoritarian Rulers of South Eastern Europe. West Lafayette, Indiana: Purdue University Press.

25. Halilović, S., Tanović, I. \& Šehović, A. (2009). Govor grada Sarajeva i razgovorni bosanski jezik. Sarajevo: Slavistički komitet. (In Bosn.).

26. Andrić, I. (1946). Letter from the Year 1920. URL: https://ia801009.us.archive.org/ 32/items/LetterFromTheYear1920_201804/Letter from the Year 1920.pdf. (accessed: 17 February 2020).

27. Bursać, A. (2006). Bosnian, Croatian, Serbian, a Grammar with Sociolinguistic Commentary. Wisconsin: The University of Wisconsin Press.

28. Škiljan, D. (1992). Standard Languages in Yugoslavia In: Language Planning in Yugoslavia. Bugarski R. and Hawkesworth C. (eds.). Columbus: Slavica Publishers, Inc. pp. $27-42$.

29. Crnobrnja, M. (1996). The Yugoslav drama. McGill-Queen's University Press.

30. Kovačić, M. (2005). Serbian and Croatian: One language or languages? Jezikoslovlje, 6 (2), $195-204$.

31. Staničić, L. (1991). Jezička politika i nominacija u Bosni i Hercegovini za vrijeme austrougarske uprave In: Književni jezik u Bosni i Hercegovini od Vuka Karadžića do kraja austrougarske vladavine. Slavica Verlag Kovač, Muenchen. pp. 99-119. (In Serb.-Croat.).

32. Vujičić, D. (1980). Naziv jezika i upotreba pisama u Bosni i Hercegovini u vrijeme austrougarske okupacije. Naučini sastanak slavista u Vukove dane, 9, 181-187. (In Serb.-Croat.).

33. Šehović, A. \& Haverić, Đ. (2017). Leksika orijentalnog porijekla u frazemama bosanskog jezika. Sarajevo: Filozofski fakultet u Sarajevu. (In Bosn.).

34. Jahić Dž., Halilović S. \& Palić I. (2000) Gramatika bosanskog jezika. Zenica: Dom štampe. (In Bosn.). 
35. Škaljić, A. (1989). Turcizmi u srpskohrvatskom jeziku. Sarajevo: Svjetlost. (In Serb.-Croat.).

36. Roberts, W.R. (1973). Tito, Mihailović, and the Allies, 1941-1945. New Brunswick, New Jersey: Rutgers University Press.

37. Hunter, T.Sh. (2017). God on Our Side: Religion in International Affairs. Lanhan, Boulder, New York, London: Rowman \& Littlefield Publishers. DOI: https://doi.org/10.1080/ 13510347.2016.1268124.

\section{Библиографический список}

1. Jelavich B. History of the Balkans, Vol. 1: Eighteenth and Nineteenth Centuries. Cambridge: Cambridge University Press, 1983.

2. Хмелевский М.C. Отражение истории, культуры и традиций Боснии в языке и фразеологии // Studia Slavica Academiae Scientiarum Hungaricae. 2015. no 60 (1). С. 79 86. DOI: https://doi.org/10.1556/060.2015.60.1.8.

3. Browne W. Serbo-Croat // The Slavonic languages, Bernard Comrie and Greville G. Corbett (eds.). London-New York: Routledge, 1993. P. 306-387.

4. Fishman J.A. The Language Factor in National Development // Anthropological Linguistics. 1962. no 4 (1). pp. 23-27.

5. Greenberg R.D. Language and identity in the Balkans: Serbo-Croatian and its disintegration. Oxford: Oxford University Press, 2008.

6. Bugarski R. Language, nationalism and war in Yugoslavia // International Journal of the Sociology of Language. 2001. no 151. pp. 69-87. DOI: https://doi.org/10.1515/ijsl.2001.048.

7. Bugarski R. Language policies in the successor states of former Yugoslavia // Journal of Language and Politics. 2004. no 3 (2). pp. 189-207. DOI: https://doi.org/10.1075/jlp.3.2.04bug.

8. Bugarski R. Portret jednog jezika / Urednik Ivan Čolović. Biblioteka XX vek, Knj. 201. Beograd: Knjižara krug, 2012.

9. Katičić R. Undoing a "Unified Language": Bosnian, Croatian, Serbian // Undoing and Redoing Corpus Planning. Clyne M. (ed.). Berlin: Mouton de Gruyter, 1997. pp. 165-191.

10. Pohl H.D. Serbokroatisch - Rückblick ind Ausblick. In: Wechselbeziehungen zwischen Slawischen Sprachen, Literaturen und Kulturen in Vergangenheit und Gegenwart. Ingeborg Ohnheiser (ed). Innsbruck: Istitut für Sprachwissenschaft, 1996. pp. 205-221.

11. Mazower M. The Balkans. Short History. New York: Modern Library, 2002.

12. Pramenković A. Muslims and Christians in the Balkans: Historical Aspect and Contemporary Challenges Dialogue without Alternative // Milel ve Nihal: Inanç, Kültür ve Mitoloji Araştirmalari. 2012. no 9 (2). pp. 113-122.

13. Anderson B. Imagined Communities: Reflections on the Origin and Spread of Nationalism. London, New York: Verso, Revised edition, 2006.

14. Labov W. Sociolinguistic Patterns. Philadelphia: University of Pennsylvania Press, 1972.

15. Isanović-Hadžiomerović A. Islamic Education in the Balkans // Daun H., Arjmand R. (eds.) Handbook of Islamic Education. International Handbooks of Religion and Education, 7. Springer, Cham, 2018. DOI: https://doi.org/10.1007/978-3-319-64683-1_47.

16. Karčić $F$. The Bosniaks and the challenges of modernity: Late Ottoman and Habsburg times. Sarajevo: El-Kalem, 1999.

17. Friedman F. Bosnia and Herzegovina: A polity on the brink. London and New York: Routledge. Taylor \& Francis Group, 2006.

18. Nasr S. H. Islam: Religion, history, and culture. New York: HarperCollins, 2009.

19. Smajić A. Bosnia and Herzegovina // J.S. Nielsen et al. (eds.), Yearbook of Muslims in Europe, 6. Leiden: Brill, 2014. pp. 108-127.

20. Tollefson J.W. (2002). The language debates: preparing for the war in Yugoslavia, 19801991 // International Journal of the Sociology of Language. 2002. no 154. pp. 65-82.

21. Lovrenović I. Bosanski Hrvati. Esej o agoniji jedne evropsko-orijentalne mikrokulture. Zagreb: Durieux, 2002.

22. Кузнеиова И.В. Устойчивые сравнения с персонажами Библии в языках бывшей Югославии // Studia Slavica Academiae Scientiarum Hungaricae. 2017. no 62 (1). pp. 7790. DOI: https://doi.org/10.1556/060.2017.62.1.7. 
23. Хмелевский М.С. Особенности фразеологии города Сараево // Национальное и интернациональное в славянской фразеологии. Грайфсвальд: Ernst-Moritz-Arndt-Universität, 2013. C. 227-231.

24. Fischer B.J. (eds.). Balkan Strongmen: Dictators and Authoritarian Rulers of South Eastern Europe. West Lafayette, Indiana: Purdue University Press, 2007.

25. Halilović S., Tanović I., Šehović A. Govor grada Sarajeva i razgovorni bosanski jezik. Sarajevo: Slavistički komitet, 2009.

26. Andrić I. (1946). Letter from the Year 1920. Режим доступа: https://ia801009.us.archive.org/ 32/items/LetterFromTheYear1920_201804/Letter from the Year 1920.pdf. (дата обращения: 17.02.2020).

27. Bursać A. Bosnian, Croatian, Serbian, a Grammar with Sociolinguistic Commentary. Wisconsin: The University of Wisconsin Press, 2006.

28. Škiljan D. Standard Languages in Yugoslavia. In: Language Planning in Yugoslavia. Bugarski R. and Hawkesworth C. (eds.). Columbus: Slavica Publishers, Inc., 1992. pp. 27—42.

29. Crnobrnja M. The Yugoslav drama. McGill-Queen's University Press, 1996.

30. Kovačić M. Serbian and Croatian: One language or languages? // Jezikoslovlje. 2005. no 6 (2). pp. 195-204.

31. Staničić L. Jezička politika i nominacija u Bosni i Hercegovini za vrijeme austrougarske uprave. In: Književni jezik u Bosni i Hercegovini od Vuka Karadžića do kraja austrougarske vladavine. München: Slavica Verlag Kovač, München, 1991. pp. 99-119.

32. Vujičić D. Naziv jezika i upotreba pisama u Bosni i Hercegovini u vrijeme austrougarske okupacije // Naučini sastanak slavista u Vukove dane. 1980. no 9. pp. 181-187.

33. Šehović A., Haverić $Đ$. Leksika orijentalnog porijekla u frazemama bosanskog jezika. Sarajevo: Filozofski fakultet u Sarajevu, 2017.

34. Jahić Dž., Halilović S., Palić I. Gramatika bosanskog jezika. Zenica: Dom štampe, 2000.

35. Škaljić A. Turcizmi u srpskohrvatskom jeziku. Sarajevo: Svjetlost, 1989.

36. Roberts W.R. Tito, Mihailović, and the Allies, 1941-1945. New Brunswick, New Jersey: Rutgers University Press, 1973.

37. Hunter T.Sh. God on Our Side: Religion in International Affairs. Lanhan, Boulder, New York, London: Rowman \& Littlefield Publishers, 2017. DOI: https://doi.org/10.1080/ 13510347.2016.1268124.

\section{Information about the authors:}

Alexandr V. Savchenko, Ph.D., Assistant Professor, Department of Slavic Languages \& Literatures, National Chengchi University (Taiwan); research interests: phraseology; lexicography and semantics; comparative linguistics; problems of interaction of language and culture, historical roots of Slavic vocabulary and phraseology; e-mail: savchenko75@mail.ru

Mikhail S. Khmelevskii, Ph.D., Associate Professor, Faculty of Philology, St.-Petersburg State University (Russia Russia); research interests: phraseology; comparative linguistics; problems of interaction of language and culture, historical roots of Slavic vocabulary and phraseology; e-mail: chmelevskij@mail.ru

\section{Информация об авторах:}

Савченко Александр Викторович, кандидат филологических наук, ассистент-профессор кафедры славянских языков и литератур Государственного университета Чжэнчжи (Тайвань); научные интересы: фразеология; лексикография и семантика; сравнительная лингвистика; проблемы взаимодействия языка и культуры, историческая лексикология и фразеология славянских языков; e-mail: savchenko75@mail.ru.

Хмелевский Михаил Сергеевич, кандидат филологических наук, доцент филологического факультета Санкт-Петербургского государственного университета (Россия); научные интере$c b l$ : фразеология; сравнительная лингвистика; проблемы взаимодействия языка и культуры, историческая лексикология и фразеология славянских языков; e-mail: chmelevskij @ mail.ru. 